\title{
Topsoil and Mulch Effects on Plant Species and Community Responses of Revegetated Mined Land
}

\author{
B.A. PINCHAK, G.E. SCHUMAN, AND E.J. DEPUIT
}

\begin{abstract}
Replacement of topsoil and the use of muiches for soil stabilization have become important components of mined land reclamation plans in the western United States. Four topsoil depths $(0,20$, 40 , and $60 \mathrm{~cm}$ ) and 2 mulch methods [crimped straw and standing barley (Hordeum vulgare L. Otis) stubble] were investigated on uranium mined land in Wyoming. Although $20 \mathrm{~cm}$ of topsoil provided initial benefits to stand establishment, after 4 growing seasons, $40 \mathrm{~cm}$ of topsoil was required to improve seeded grass growth over that found in non-topsoiled plots. Forty centimeters of topsoil was also found to result in the lowest biomass of invading annual and biennial forbs (nonseeded species). Barley stubble mulch resulted in significantly $(P=0.05)$ higher biomass of seeded grass species than did crimped straw mulch when at least $40 \mathrm{~cm}$ of topsoil was present.
\end{abstract}

Despite a decline in energy demand in the early part of this decade, coal and uranium mining continues to disturb hundreds of hectares in Wyoming each year. Reclamation of these lands must be a prime consideration in mining if productive rangeland is not to be lost. The application of topsoil and use of mulches as temporary site stabilizers have become important components of many surface mine reclamation programs. Questions remain, however, as to the amount of topsoil required for sustained site productivity and the type of mulch best suited to particular reclamation needs.

Regulations at both federal and state levels now require salvage and redistribution of topsoil on mined areas. Numerous studies have shown that depth of reapplied topsoil and topsoil plus subsoil significantly influence aboveground plant production (Power et al. 1979, Schuman et al. 1984, Schuman and Power 1981), root growth (McGinnies and Nicholas 1980), and soil water relationships (Power et al. 1981, Schuman et al. 1980) on mined land. Quality of topsoil and spoil materials, climatic factors, seeded plant species requirements, and concurrent reclamation practices all appear to influence the optimal topsoil depth for a given area.

Widespread use of mulches on mined sites has been based upon findings that mulches provide needed soil stabilization (Jones et al. 1969, Meyer et al. 1970), promote water conservation (Hopkins 1954, Winterlin et al. 1958, Dudeck et al. 1970), and often shorten the time needed for adequate plant establishment (Farmer et al. 1974, Aldon 1978). At present, straw and hay mulches are most commonly used in the Northern Great Plains. A number of studies have also evaluated the suitability of various annual species as temporary stabilizers (Sindelar et al. 1973, Dollhopf and Majerus 1975, DePuit et al. 1978). Further interest in stubble mulching has been promoted by the findings of Schuman et al. (1980). Stubble mulching has been reported to result in equal or greater establishment of perennial grasses than has straw mulch and at 75 to $95 \%$ of the cost.

This study was conducted to evaluate vegetation responses on

\footnotetext{
Authors are research associate, Natural Resource Ecology Laboratory, Colorado State University, Fort Collins 80523 (former graduate assistant, Range Management Division, University of Wyoming, Laramie 82071); soil scientist, USDA, Agricultural Research Service, 8408 Hildreth Road, Cheyenne, Wyo. 82009; and assistant professor, Range Management Division, University of Wyoming, Laramie, Wyo. 8207I.

This research is a contribution from the USDA Agricultural Research Service and the Wyoming Agricultural Experiment Station. Published as Journal Article Series paper JA 1298, Wyoming Agricultural Experiment Station.

Manuscript accepted August 23, 1984.
}

seeded uranium mined lands to varied topsoil depth and mulch type.

\section{Methods and Procedures}

The study area was located at the Pathfinder Mines Corporation's Shirley Basin Uranium Mine in southcentral Wyoming. The climate of the area is cold and semiarid. Average annual precipitation is $26 \mathrm{~cm}$, about one-third of which is received as snowfall. The frost-free growing season ranges from 60 to 90 days.

Elevation of the mine site ranges from 2,117 to $2,151 \mathrm{~m}$ and the undisturbed terrain consists of low rolling hills. Native vegetation in the area is dominated by a sagebrush-grass association with big sagebrush (Artemisia tridentata ssp. wyomingensis Beetle \& Young) and fringed sagewort ( $A$. frigida Willd.), the dominant shrubs, and western wheatgrass (Agropyron smithii Rydb.), bluebunch wheatgrass [A. spicatum (Pursh) Scribn. \& Smith/Cult./], and needleandthread (Stipa comata Trin. \& Rupr.) the dominant grass species. Land uses prior to mining were primarily livestock grazing and wildlife habitat.

The study was initiated in 1977 when topsoil (A and B horizon material) was spread in a wedge configuration over a regraded spoil dump (Fig. 1). The soil from which the topsoil was obtained

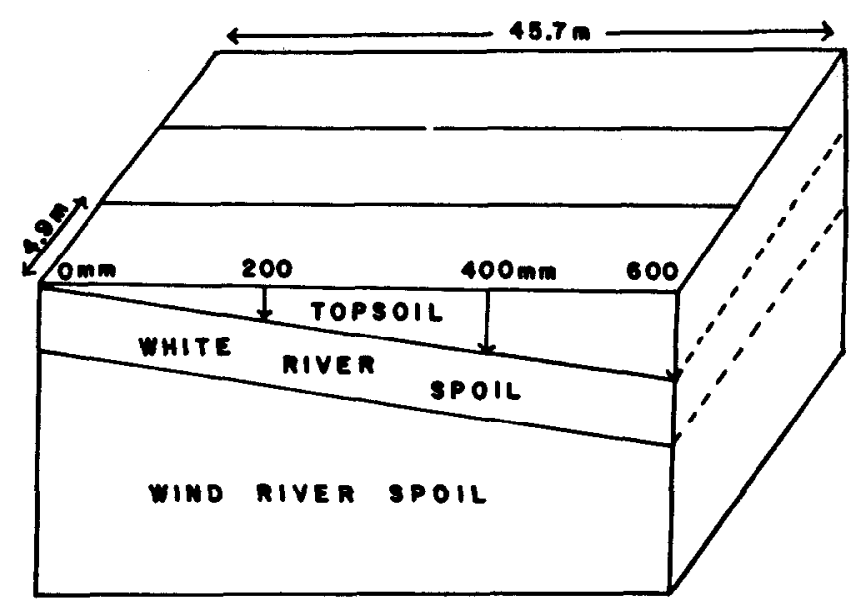

Fig. 1. Diagram of reconstructed soil with variable topsoil depths.

was a fine loamy, mixed Borollic Haplargid, with a pH of 7.1, electrical conductivity of $2.5 \mathrm{dS} / \mathrm{m}$, and organic matter content of $2.4 \%$. Topsoil material was direct applied over a 1-meter layer of spoil derived from coarse-grained sandstones of the White River Formation. Spoil material below this layer consisted of calcareous and moderately well-cemented siltstones and claystones of the Wind River Formation. Organic matter, nitrogen $(\mathrm{N})$, and phosphorus $(P)$ were extremely low in both spoil types. However, these spoils contained no toxic concentrations of any element. Plots received $P$ and $N$ fertilization at average rates of $67 \mathrm{~kg} \mathrm{P} / \mathrm{ha}$ and $315 \mathrm{~kg} \mathrm{~N} / \mathrm{ha}$.

The study area was divided into 20 plots ( 4.9 by $45.7 \mathrm{~m}$ ), running 
parallel to the topsoil depth gradient. In spring 1977 , one-half of these plots were drill seeded with $50 \mathrm{~kg}$ / ha 'Otis' barley (Hordeum vulgare $\mathrm{L}$.) to establish the stubble mulch treatment; the remaining 10 plots were left fallow for future application of the straw mulch treatment. In October 1977 all plots were drill seeded at rates to apply equal numbers of seeds of 'Critana' thickspike wheatgrass [Agropyron dasystachyum (Hook.) Scribn.], green needlegrass (Stipa viridula Trin.), slender wheatgrass [A. trachycaulum (Link.) Malte], and 'Rosana' western wheatgrass ( $A$. smithii Rydb.) at a total seeding rate of $15.5 \mathrm{~kg} /$ ha pure live seed. Barley straw was hand scattered on the previously fallowed plots at a rate of $5 \mathrm{mt} / \mathrm{ha}$ and crimped in 2 directions.

Four topsoil depths, $0,20,40$, and $60 \mathrm{~cm}$, were chosen for sampling along the topsoil gradient. Following the active growing seasons in 1979 and 1980, aboveground biomass was hand harvested utilizing a $0.18-\mathrm{m}^{2}$ sampling quadrat (no vegetation data were collected the first season, 1978, due to limited seedling growth). Four sampling quadrats, one at each topsoil depth, were located within each of the $\mathbf{2 0}$ main plots. Harvested vegetation was grouped as seeded species, other perennial grasses, and annual forbs. In 1981, sampling intensity was doubled to allow analysis of responses of individual seeded species as well as the aforementioned species groups. Canopy cover was estimated utilizing a 20 by $50 \mathrm{~cm}$ sampling quadrat and modification of the Daubenmire canopy-cover method (Daubenmire 1959). Canopy cover for individual species and species groups was estimated to the nearest whole percent, as opposed to the use of cover classes as suggested by Daubenmire.

All data were analyzed with analysis of variance using a factorial design $(P=0.05)$ with topsoil depth and mulch type as variables. Least significant difference was used to evaluate mean differences for all parameters.

\section{Results and Discussion}

The effects of mulch type in 1981 and previous years indicated a distinct superiority of stubble mulch in promoting growth of seeded grasses (Schuman et al. 1985). Analysis of interactive effects of mulch type and topsoil depth on total seeded species biomass in 1981, however, indicated that the superiority of stubble over straw mulch was limited to plots receiving 40 and $60 \mathrm{~cm}$ of topsoil (Fig. 2).

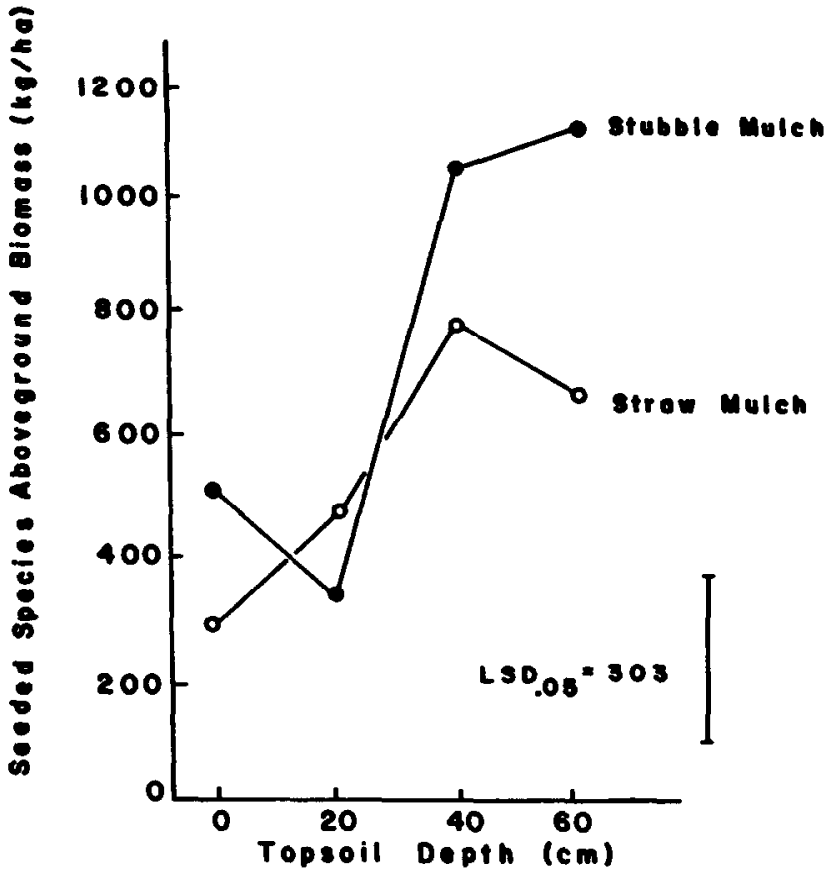

Fis. 2. Seeded species aboveground biomass response to mulch type $X$ topsoil depth interaction, Shirley Basin, Wyoming, 1981.
Barley production in 1977 on stubble mulch plots increased with topsoil thickness, with major progressive increases occurring with the addition of 20 and $40 \mathrm{~cm}$ of topsoil and a lesser increase when $60 \mathrm{~cm}$ of topsoil was added (Schuman et al. 1980). Degree of benefit from stubble mulching may therefore be attributed, at least in part, to stubble crop production potential, which may be influenced by topsoil depth. It should be noted, however, that even under conditions of sub-maximal barley growth at 0 and $20 \mathrm{~cm}$ topsoil depth, stubble mulching was at least as effective in promoting growth of seeded grass species as was straw mulching. However, the straw mulch would give immediate protection to the soil resource, whereas the stubble method leaves the soil more susceptible to erosion during its establishment.

In 1981, biomass of nonseeded species was found to be lower in the $40 \mathrm{~cm}$ topsoil treatment than in the 0,20 , or $60-\mathrm{cm}$ topsoil plots. However, the significance of this pattern was limited to the stubble mulch treatment (Fig. 3). An unusually wet May in 1981, plus a

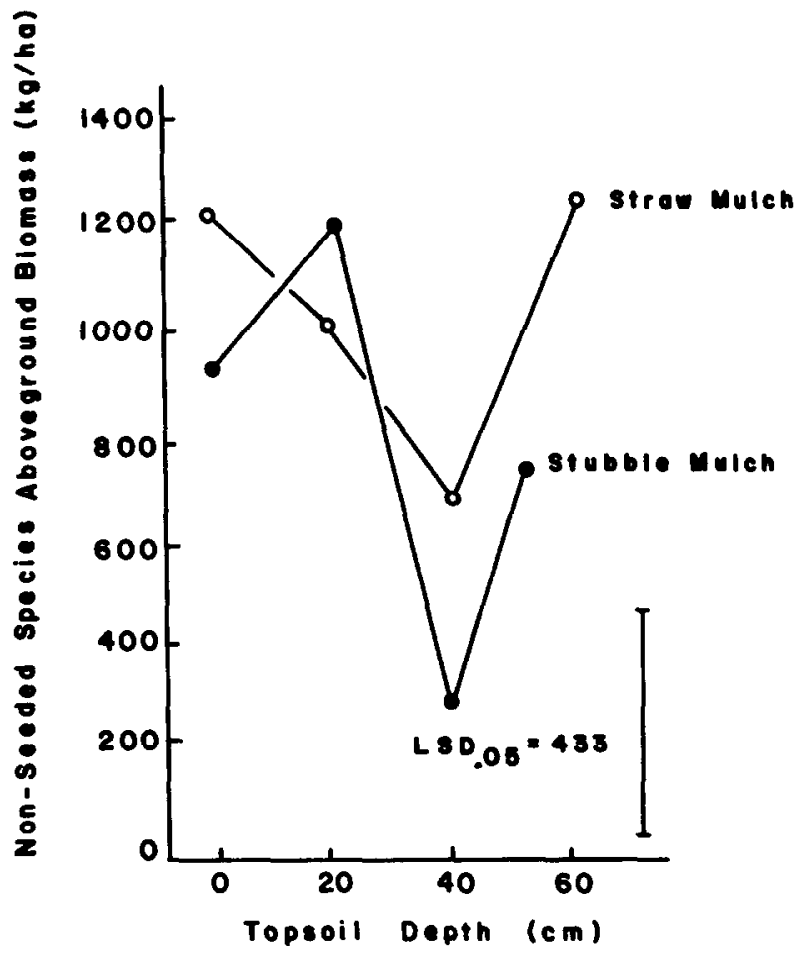

Fig. 3. Response of annual and biennial forb aboveground biomass to mulch type $\times$ topsoil depth interaction, Shirley Basin, Wyoming, 1981.

decrease in slender wheatgrass, may account for the $135 \%$ average increase in nonseeded species biomass over the preceding year (Table 1). Summercypress [Kochia scoparia (L.) Roth] was the

Table 1. Aboveground biomass response to topsoil depth, Shirley Basin, Wyoming 1979-1981.

\begin{tabular}{|c|c|c|c|c|c|c|}
\hline \multirow{2}{*}{$\begin{array}{l}\text { Topsoil } \\
\text { Depth }\end{array}$} & \multicolumn{3}{|c|}{ Seeded Species } & \multicolumn{3}{|c|}{ Non-seeded Species ${ }^{2}$} \\
\hline & 1979 & 1980 & 1981 & 1979 & 1980 & 1981 \\
\hline $\mathrm{cm}$ & \multicolumn{6}{|c|}{$-\mathrm{kg} / \mathrm{ha}$} \\
\hline 0 & 180 & 274 & 410 & 448 & 689 & 1115 \\
\hline 20 & 372 & 356 & 446 & 243 & 370 & 1133 \\
\hline 40 & 445 & 689 & 968 & 323 & 245 & 605 \\
\hline 60 & 671 & 756 & 984 & 408 & 189 & 952 \\
\hline LSD. $.05^{3}$ & & 202 & & & 212 & \\
\hline
\end{tabular}

iValues represent mean across mulch type and biomass is on a dry-weight basis. 2Non-seeded species were predominately composed of Kochia scoparia, Descurainia pinnata, Polygonum aviculare, Salsola kali and Hordeum jubatum.

${ }^{3} \mathrm{LSD} .06$ values used to evaluate means for all years for seeded species and all years for non-seeded species. 
Table 2. Individual seeded species biomass response to topsoil depth and mulch type, Shirley Basin, Wyoming, 1981.

\begin{tabular}{|c|c|c|c|c|c|c|c|c|}
\hline \multirow{2}{*}{$\begin{array}{l}\text { Topsoil } \\
\text { Depth }\end{array}$} & \multicolumn{2}{|c|}{ Western wheatgrass } & \multicolumn{2}{|c|}{ Thickspike wheatgrass } & \multicolumn{2}{|c|}{ Green needlegrass } & \multicolumn{2}{|c|}{ Slender wheatgrass } \\
\hline & Stubble & Straw & Stubble & Straw & Stubble & Straw & Stubble & Straw \\
\hline \multicolumn{9}{|l|}{$\mathrm{cm}$} \\
\hline 0 & 74 & 98 & 278 & 184 & 71 & 25 & 109 & 8 \\
\hline 20 & 62 & 88 & 239 & 235 & 69 & 77 & 0 & 109 \\
\hline 40 & 143 & 158 & 601 & 484 & 291 & 152 & 23 & 38 \\
\hline \multirow{2}{*}{$\begin{array}{l}60 \\
\mathrm{LSD}_{.05}{ }^{1}\end{array}$} & 138 & 169 & 701 & 425 & 250 & 111 & 23 & 6 \\
\hline & \multicolumn{2}{|c|}{-120} & 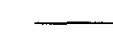 & - & \multicolumn{2}{|c|}{$-128-\ldots$} & \multicolumn{2}{|c|}{$-140-1$} \\
\hline
\end{tabular}

'LSD.0s values used to evaluate means within a species for both mulch types.

primary species in this group. The relatively low average biomass of slender wheatgrass in 1981 , regardless of topsoil depth or mulch type (Table 2), was not unexpected due to the often-noted short lived nature of this species on disturbed land (Schuman et al. 1982). Slender wheatgrass was a major component of seeded grass biomass on the site in 1979 , but steadily declined to the levels found in 1981 (Schuman, G.E. personal communication).

Responses of individual seeded species to mulch type (and topsoil depth) in 1981 are given in Table 2. Thickspike wheatgrass and green needlegrass followed a pattern similar to that of seeded species in aggregate. Both species exhibited greater mean (across all topsoil depths) biomass under stubble than under straw mulching. However, biomass for both species was substantially higher under stubble mulching only at $\mathbf{4 0}$ and $60 \mathrm{~cm}$ of topsoil (Table 2). Neither western nor slender wheatgrass exhibited consistent or significant differences between mulch types/among topsoil depths.

Superior total seeded species growth under stubble mulching with adequate $(40$ to $60 \mathrm{~cm})$ topsoil in this study may have been the result of greater water availability than that achieved under straw mulching during seeded perennial species establishment. In 1978, cumulative infiltration was $25 \%$ higher for the stubble mulch treatment than for the straw mulch treatment (Schuman et al. 1980). Despite positive effects of stubble mulching on seeded species growth and in contrast to topsoil depth treatments, mulch type had no significant differential effects on measures of plant community diversity ( $\mathrm{H}^{\prime}$-diversity index and richness) in 1981.

Under both mulch methods, total seeded species biomass in 1981 was significantly higher at 40 and $60 \mathrm{~cm}$ topsoil than at 0 and $20 \mathrm{~cm}$ topsoil (Fig. 2). This topsoil depth trend was also apparent in 1981 total seeded species biomass data averaged across mulch type (Table 1). Individual seeded species data (Table 2) for 1981 also suggest the same trend for western wheatgrass, thickspike wheatgrass and green needlegrass under both mulch methods, although sampling variability precluded statistically significant $0 / 20 \mathrm{~cm}$ vs. $40 / 60 \mathrm{~cm}$ topsoil differences for all species except thickspike wheatgrass and green needlegrass under stubble mulching. Thus, vegetation responses to varied topsoil depth were generally similar with each mulch type in 1981 . Therefore, to further evaluate topsoil depth effects on biomass (seeded and nonseeded species) among years, 1979 through 1981 data were averaged across mulch type.

Seeded and nonseeded species biomass response to topsoil depths under investigation are shown in Table 1. In 1979, biomass of seeded species in aggregate consistently increased with increasing topsoil depth, with maximum production occurring at $60 \mathrm{~cm}$ of reapplied topsoil. This pattern agrees with initial results of other studies in the Northern Great Plains (Power et al. 1979, Barth 1980). Biomass data for 1980 and 1981 , however, indicated that effects of topsoil depth on seeded species production changed rapidly in initial years following reseeding. Data of 1979 demonstrated the initial value of shallow topsoil depths in increasing biomass of seeded grasses over that where no topsoil was reapplied. Twenty centimeters of topsoil increased seeded grass yields by more than 100\% over that of non-topsoiled plots in 1979; however this large difference was not significant due to variability. Similar benefits from additions of as little as $20 \mathrm{~cm}$ of topsoil were found by
Farmer et al. (1974). Biomass data of 1980 indicated a declining differential response of seeded grasses to shallow vs. no topsoil replacement. Although biomass of seeded species in plots receiving the $20-\mathrm{cm}$ topsoil treatment remained higher than that on plots receiving no topsoil, this difference was substantially lower than found in 1979 and was not statistically significant.

Any initial benefits of shallow topsoil replacement had become negligible by the end of the 1981 growing season. Little difference in seeded grass biomass was found between 0 and $20 \mathrm{~cm}$ topsoil. This suggests that as the plant roots penetrate the underlying soil, benefits derived from a shallow topsoil layer can be expected to diminish. Cumulative effects of vegetation growth in promoting biological and physical development of surface spoil layers in 0-cm plots may comprise another causal factor for this relationship in 1981.

Initial (1979) advantages to seeded grasses of $60 \mathrm{~cm}$ of topsoil over the 40 -cm depth treatment were lost by 1980 . Between 1979 and 1981 seeded grass biomass in $60-\mathrm{cm}$ plots exhibited a slower rate of increase than in plots receiving the $40-\mathrm{cm}$ treatment, the combined result of lower spring soil moisture and greater invasion by nonseeded species at the $60 \mathrm{~cm}$ depth (Table 1). No significant differences in seeded species biomass were found between 40 and $60 \mathrm{~cm}$ topsoil plots in 1980 and 1981 .

Effects of topsoil depth treatments on apparent plant community diversity were assessed by use of richness (species numbers) data and a calculated diversity index, the Shannon-Wiener Function (H) (Shannon and Weaver 1973). Mulch type did not have any significant effect on total canopy cover, therefore the diversity index and richness values calculated were averaged across mulch type. Diversity indices $\left(\mathrm{H}^{\prime}\right)$ showed no differences among the 20 , 40 , and $60 \mathrm{~cm}$ topsoil depths (Table 3). Richness values followed a

Table 3. Effects of varied topsoil depth on plant community diversity parameters, Shirley Basin, Wyoming, 1981. (All values are means of both mulch treatments).

\begin{tabular}{ccc}
\hline \hline $\begin{array}{c}\text { Topsoil Depth } \\
\mathrm{cm}\end{array}$ & $\begin{array}{c}\text { Shannon-Wiener } \\
\text { Diveristy index }\left(\mathbf{H}^{1}\right)^{1}\end{array}$ & $\begin{array}{c}\text { Mean species } \\
\text { Richness }\end{array}$ \\
\hline 0 & 0.398 & 4.0 \\
20 & 0.429 & 4.7 \\
40 & 0.479 & 5.2 \\
60 & 0.451 & 4.9 \\
LSD.05 & 0.076 & 0.7 \\
\hline
\end{tabular}

IShannon and Weaver (1973), derived from canopy cover data.

${ }_{2}^{2}$ SDD.06 $_{.01}$ vaes used to evaluate means within a parameter.

similar pattern. Although $\mathrm{H}^{\prime}$ and richness were both significantly higher at $40 \mathrm{~cm}$ of topsoil than in non-topsoiled plots, there were no significant differences for either parameter between 20 and 60 $\mathrm{cm}$ of topsoil depth. Therefore, the only conclusions that may be drawn are that application of topsoil at the depth necessary for maximum production also significantly improved diversity over that achieved with no topsoil replacement, but that variations in topsoil depth from 20 to $60 \mathrm{~cm}$ had negligible effects on diversity.

The diversity data, combined with seeded species and nonseeded species biomass data, suggest that the optimal topsoil depth 
for reclamation of a given site may be quite specific. The trend of higher nonseeded species biomass of the 0 and $20-\mathrm{cm}$ topsoil treatments in 1979-1981 can be attributed to lower seeded grass competition under the suboptimal soil conditions of these treatments. High nonseeded species biomass at the $60 \mathrm{~cm}$ topsoil depth in 1981, however, may indicate that topsoil depths in excess of those needed to provide peak growth of seeded species may result in slowed successional development of revegetated mined lands. The reason for greater nonseeded species biomass with $60 \mathrm{~cm}$ of topsoil in 1981 is not known, but may be related to differential benefits of thicker topsoil on the deeper, taprooted annual Kochia compared to the relatively shallow rooted dominant rhizomatous wheatgrasses (thickspike and western wheatgrass).

\section{Conclusions}

Stubble mulching resulted in significantly greater biomass of perennial grass species than straw mulching only when topsoil depths were $40 \mathrm{~cm}$ or greater. Lack of significant effects of mulch type on perennial grass production at the 0 and $20 \mathrm{~cm}$ topsoil depths was attributed to submaximal barley stubble production at these depths.

The response of seeded species biomass to topsoil depth was found to change rapidly during initial years following seeding. After 4 growing seasons (1981), $40 \mathrm{~cm}$ of topsoil was found to be best in terms of seeded species production and limited infestation of non-seeded species. While providing initial benefits to stand establishment, $20 \mathrm{~cm}$ of topsoil yielded no significant improvement in seeded species biomass over that where no topsoil was replaced by the fourth season (1981). Plant community diversity showed no differences between 20,40 , and $60 \mathrm{~cm}$ of replaced topsoil or mulch type.

\section{Literature Cited}

Aldon, E.F. 1978. Reclamation of coal-mined land in the Southwest. J. Soil and Water Conserv. 32:75-79.

Barth, R.C. 1980. Soil depth requirements for reclamation of surface mined lands. 1979 Prog. Rep. Colorado School of Mines Research Institute, Golden, Colo.

DePuit, E.J., J.G. Coenenberg, and W.H. Willmuth. 1978. Research on revegetation of surface mined lands at Coalstrip, Montana: Prog. Rep. 1975-1977. Montana Agr. Exp. Sta. Res. Rep. 127. Bozeman, Mont.
Dollhopf, D.J., and M.E. Majerus. 1975. Strip mine reclamation research located at Decker Coal Company, Decker, Mont. Montana Agr. Exp. Sta. Res. Rep. 83. Bozeman.

Dudeck, A.E., N.P. Swanson, L.N. Meilke, and A.R. Dedrick. 1970. Mulches for grass establishment on fill slopes. Agron. J. 62:810-812.

Farmer, E.E., R.W. Brown, B.Z. Richardson, and P.E. Packer. 1974. Revegetation research on the Decker Coal Mine in southeastern Montana. USDA Forest Serv. Res. Pap. INT-162. Ogden, Utah.

Hopkins, H.H. 1954. Effects of mulch on certain factors of the grassland environment. J. Range Manage. 7:255-258.

Jones, J.N., Jr., J.E. Moody, and J.H. Lillard. 1969. Effects of tillage, no tillage and mulch on soil water and plant growth. Agron. J. 61:719-721.

McGinnies, W.J., and P.J. Nicholas. 1980. Effects of topsoil thickness and nitrogen fertilizer on the revegetation of coal mine spoils. J. Environ. Qual. 9:681-685.

Meyer, L.D., W.H. Wischmejer and G.R. Foster. 1970. Mulch rates required for erosion control on steep slopes. Soil Sci. Soc. Amer. Proc. 34:928-931.

Power, J.F., F.M. Sandoval, R.E. Ries, and S.D. Merrill. 1981. Effects of topsoil and subsoil thickness on soil water content and crop production on a disturbed soil. Soil Sci. Soc. Amer. J. 45:124-129.

Power, J.F., F.M. Sandoval, and R.E. Ries. 1979. Topsoil-subsoil requirements to restore North Dakota mined land to original productivity. Soc. Mining Engin. Dec. 1979:1708-1712.

Schuman, G.E., E.M. Taylor, Jr., R. Rauzi, and G.S. Howard. 1980. Standing stubble vs. crimped straw mulch for establishing grass on mined lands. J. Soil and Water Conserv. 35:25-27.

Schuman, G.E., and J.F. Power. 1981. Topsoil management on mined lands. J. Soil and Water Conserv. 36:77-78.

Schuman, G.E., F. Rauxi, and D.T. Booth. 1982. Production and competition of crested wheatgrass-native grass mixtures. Agron. J. 74:23-26.

Schuman, G.E., E.M. Taylor, Jr., F. Rauzi, and P.A. Pinchak. 1985. Revegetation of mined lands as influenced by topsoil depth and mulch method. J. Soil and Water Conserv. (In Press).

Shannon, C.E., and W. Weaver. 1973. The mathematical theory of communication. University of Illinois Press, Urbana.

Sindelar, B.W., R.L. Hodder, and M.E. Majerus. 1973. Surface mined land reclamation in Montana. Prog. Rep. 1972-1973. Montana Agr. Exp. Sta. Res. Rep. 40, Bozeman, Mont.

Winterlin, W.L., T.M. McCalla, and R.E. Leubs. 1958. Stubble mulch tillage versus plowing with nitrogen fertilization with regard to nutrient uptake by cereals. Agron. J. 50:241-243.

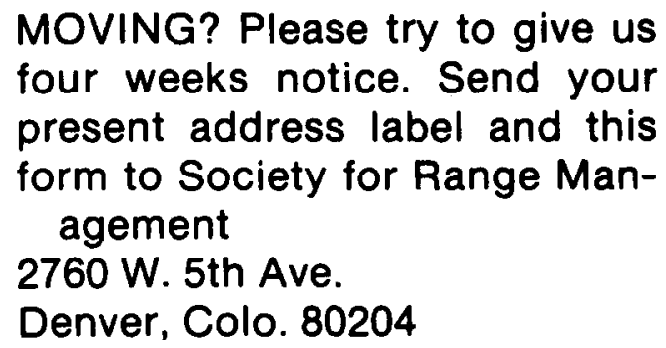

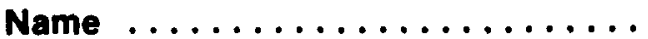

New Address $\ldots \ldots \ldots \ldots \ldots \ldots \ldots$

City $\ldots \ldots \ldots \ldots \ldots \ldots \ldots \ldots$

State

\author{
ATTACH OLD \\ ADDRESS LABEL \\ HERE
}

